\title{
Analisis Faktor-faktor yang Mempengaruhi Penerapan Standar Akuntansi Keuangan Entitas Mikro Kecil dan Menengah (SAK EMKM) dalam Penyusunan Laporan Keuangan (Study Kasus pada UMKM Kecamatan Makasar, Jakarta Timur)
}

\author{
Tutik Siswanti \\ Universitas Dirgantara Marsekal Suryadarma \\ Indah Suryati \\ Universitas Dirgantara Marsekal Suryadarma \\ tutysis12@gmail.com
}

\begin{abstract}
Abstrak
Tujuan penelitian ini adalah untuk mengetahui faktor-faktor apa saja yang mempengaruhi penerapan SAK EMKM dalam penyusunan laporan keuangan pada kegiatan Usaha Mikro Kecil dan Menengah di Wilayah Jakarta Timur, tepatnya di Kecamatan Makasar. Jenis penelitian yang digunakan adalah penelitian kuantitatif, sedangkan metode penelitian yang digunakan adalah deskriptif asosiatif. Populasi dalam penelitian ini pelaku UMKM, teknik sampling yang digunakan random sampling. Pengumpulan data dilakukan dengan penyebaran angket tertutup, dimana reponden menjawab pertanyaan yang telah disediakan jawabannya. Hasil penelitian ini menunjukkan bahwa faktor yang dominan mempengaruhi penerapan SAK EMKM dalam penyusunan laporan keuangan adalah Ukuran Perusahaan dan Kompetensi Sumber Daya Manusia.Berdasarkan hasil persamaan regresi menunjjukan, bahwa koefisen nilai ukuran perusahaan dan Komptensi SDM memiliki hubungan positif searah dengan penerapan SAK EMKM dalam penyusunan laporan keuangan.Hasil ini juga diperkuat dengan hasil uji hipotesis, dimana secara parsial dan simultan kedua variabel tersebut berpengaruh terhadap penerapan SAK EMKM. Hasil koefisien determinasi menunjukkan kemampuan varian variabel ukuran perusahaan dan komptensi SDM menjelaskan varian dari penerapan SAK EMKM dalam penyusunan laporan keuangan sebesar $67,5 \%$
\end{abstract}

Kata Kunci : Laporan Keuangan, Penerapan SAK EMKM, Ukuran Usaha, Kompetensi,Sumber Daya Manusia, UMKM

\section{Pendahuluan}

Usaha Mikro Kecil dan Menengah (UMKM) merupakan ekonomi rakyat yang memiliki lingkup kecil yang berdiri sendiri dan dikelola oleh perorangan atau kelompok. Pengembangan UMKM di Indonesia merupakan salah satu prioritas dalam pembangunan ekonomi nasional. Berdasarkan data Badan Pusat Statistik (BPS) jumlah pelaku usaha mikro kecil dan menengah (UMKM) di Indonesia pada 2019 sebanyak 59,2 juta orang (sumber: kominfo.go.id, 2019). Sedangkan jumlah penduduk Indonesia pada tahun 2019 diproyeksikan mencapai 266,91 juta jiwa (sumber: Databoks.katadata.co.id, 2019). Dari data tersebut menyatakan bahwa seperempat dari penduduk Indonesia berkontribusi membuka lahan usaha maupun menumbuhkan perekonomian dalam bidang UMKM.

Kriteria Usaha Mikro Kecil dan Menengah (UMKM) telah diatur oleh (UU No. 20 Tahun 2008, 2008). Pengertian UMKM adalah peluang usaha produktif milik orang 


\section{Tutik Siswanti, Indah Suryati}

perorangan atau badan usaha perorangan yang memenuhi kriteria usaha mikro sebagaimana diatur oleh undang-undang. Usaha kecil adalah peluang usaha ekonomi produktif yang berdiri sendiri, yang dilakukan oleh orang perorangan atau badan usaha yang bukan merupakan anak perusahaan atau bukan cabang perusahaan yang dimiliki, dikuasai, atau menjadi baik langsung maupun tidak langsung dari usaha menengah atau usaha besar yang memenuhi kriteria usaha kecil sebagaimana yang dimaksud dalam undang-undang.

Berbagai persoalan dihadapi UMKM dalam menjalankan usahanya, beberapa UMKM tidak dapat berkembang dan tumbuh, selain faktor permodalan dan SDM yang belum memadai, permasalahan yang tidak kalah penting adalah berkaitan dengan sistem pencatatan dan pelaporan atas transaksi usahanya. Sebagian UMKM tidak melakukan pencatatan dan membuat laporan keuangan atas kegiatan usahanya secara rutin dan benar. Hal ini menyebabkan pelaku UMKM tidak dapat mengukur, dan menilai kinerja keuangannya dengan tepat dan benar, sehingga beberapa keputusan keuangan tidak dilakukan berdasarkan informasi yang akurat. Kegiatan usaha yang tidak terukur, pertumbuhan usaha, laba, pendapatan, aset, modal dan kelayakan usaha yang menjadi informasi penting dalam perencanaan, evaluasi, dan penyusunan strategi usaha tidak tersedia secara lengkap, transparan, dan rutin membuat kegiatan UMKM tidak dapat berkembang. Kondisi ini juga terjadi pada UMKM di Kecamatan Makasar, Jakarta Timur. Sebagian dari pelaku UMKM tidak menyusun laporan keuangan sesuai dengan standar yang berlaku, dengan alasan bahwa kegiatan usaha tersebut hanya dipertanggungjawabkan untuk diri pribadi, karena usaha milik perorangan. Selain itu juga tidak adanya sumber daya manusia atau karyawan yang memahami dan memiliki pengetahuan dalam penyusunan laporan keuangan yang benar. Beberapa pelaku UMKM telah melakukan penyusunan laporan keuangan secara rutin, dan benar sesuai standar akuntansi yang berlaku karena berbagai pertimbangan, antara lain adalah kegiatan usaha telah lama dijalankan dan juga aset perusahaan, pelanggan, wilayah pemasaran, perputaran aset yang sudah cukup besar, dan juga telah memiliki karyawan atau SDM yang memilki pengetahuan tata cara penyusunan laporan keuangan sesuai dengan SAK.

Sesuai ketentuannya bahwa untuk usaha kecil dalam menyusun laporan keuangan harus menggunakan SAK-EMKM. SAK-EMKM merupakan bentuk dukungan Ikatan Akuntan Indonesia (IAI, 2019) dalam meningkatan penegakan transparasi dan akuntanbilitas pelaporan entitas.SAK-EMKM merupakan standar akuntansi yang sudah disederhanakan dalam mengatur transaksi yang umum dilakukan UMKM dan dasar pengukurannya menggunakan biaya historis (David, 2018) SAK-EMKM baru mulai berlaku sejak 1 Januari 2018.

Manfaat yang di peroleh jika pelaku usaha UMKM menyusun laporan keuangan sesuai dengan SAK EMKM ialah mendapatkan informasi seperti : ( (Muslichah, 2018)
a. Informasi Kinerja perusahaan
b. Informasi posisi dana perusahaan
c. Informasi perubahan modal pemilik
d. Informasi penerimaan dan pengeluaran kas
e. Informasi besaran biaya

SAK-EMKM juga dapat digunakan pengusaha untuk melihat pertumbuhan usaha, mengevaluasi usaha, menyusun strategi dan dapat mengajukan pinjaman penambahan modal.

Beberapa penelitian telah dilakukan sebelumnya, (Suastini, 2019), menyimpulkan bahwa ukuran usaha akan mempengaruhi pemilik usaha untuk menentukan langkah dalam memutuskan untuk menggunakan standar akuntansi dalam menyusun laporan keuangan. (Purba, 2019), menyimpulkan antara lain ketidakmampuan manajemen UMKM dalam 
menyusun laporan keuangan yang sesuai dengan SAK EMKM, disebabkan oleh beberapa hal, yaitu ketidaktahuan manajemen terhadap SAK-EMKM serta kurangnya SDM yang memiliki kompetensi atau pemahaman terkait penyusunan laporan keuangan

Berdasarkan latar belakang masalah tersebut, maka dalam penelitian ini akan menkaji dan menanalisis permasalahan terkait dengan faktor-faktor yang mempengaruhi penerapan SAK EMKM dalam penyusunan laporan keuangan bagi UMKM di Wilayah Jakarta Timur. Adapun perumusan masalah dalam penelitian ini adalah sebagai berikut :

a. Bagaimana Pengaruh Ukuran Usaha terhadap Penerapan SAK EMKM dalam Penyusunan Laporan Keuangan secara parsial

b. Bagaimana Pengaruh Lamanya Usaha terhadap Penerapan SAK EMKM dalam Penyusunan Laporan Keuangan secara parsial

c. Bagaimana Pengaruh Ukuran Usaha dan Lamanya Usaha terhadap Penerapan SAK EMKM dalam Penyusunan Laporan Keuangan secara simultan

\section{Landasan Teori}

\section{Standar Akuntansi Keuangan (SAK)}

Menurut (IAI, 2019) mendefinisikan sebagai berikut :

"Standar Akuntansi Keuangan (SAK) adalah Pernyataan Standar Akuntansi Keuangan (PSAK) dan Interpretasi Standar Akuntansi Keuangan (ISAK) yang diterbitkan oleh Dewan Standar Ikatan Akuntan Indonesia (DSAK IAI) dan Dewan Standar Syariah Ikatan Akuntan Indonesia (DSAS IAI) serta peraturan regulator pasar modal untuk entitas yang berada di bawah pengawasannya".

Menurut Suwardjono dalam penelitian (Uno M.O, 2019) mendefinisikan : "Standar Akuntansi Keuangan merupakan konsep, prinsip, metoda, teknik dan lainnya yang sengaja dipilih atas dasar kerangka konseptual oleh badan penyusun standar (atau yang berwenang) untuk diberlakukan dalam suatu lingkungan atau negara dan dituangkan dalam bentuk dokumen resmi guna mencapai tujuan pelaporan keuangan negara tersebut”.

Tujuan ditetapkannya Standar Akuntansi Keuangan adalah menetapkan dasar-dasar bagi penyajian laporan keuangan untuk umum. Menurut (Muslichah, 2018, hal. 20) tujuan tersebut adalah :

a. Untuk keseragaman, laporan keuangan yang relevan dan reliable.

b. Memudahkan penyusunan laporan keuangan karena adanya pedoman baku sehingga meminimalkan bias dari penyusunan.

c. Memudahkan auditor dalam mengaudit.

d. Memudahkan pembaca laporan keuangan untuk menginterpretasikan dan membandingkan laporan keuangan entitas yang berbeda.

e. Pengguna laporan keuangan banyak pihak sehingga penyusun tidak dapat menjelaskan kepada masing-masing pengguna. 


\section{Standar Akuntansi Keuangan Entitas Mikro Kecil dan Menengah (SAK-EMKM)}

Menurut Ikatan Akuntan Indonesia SAK EMKM adalah Exposure Draft Standar Akuntansi Keuangan Entitas Mikro Kecil dan Menengah (ED SAK EMKM) pernyataan standar akuntansi keuangan yang jauh lebih sederhana bila dibandingkan dengan SAK ETAP.

Menurut (Yuli Rawun, 2019) mendefinisikan sebagai berikut: "SAK EMKM adalah standar akuntansi yang ditujukan untuk memenuhi kebutuhan pelaporan keuangan entitas mikro, kecil, dan menengah. Laporan keuangan pada SAK EMKM hanya meliputi laporan laba rugi, laporan posisi keuangan, dan catatan atas laporan keuangan"

Berdasarkan pengertian diatas dapat disimpulkan bahwa Standar Akuntansi Keuangan Entitas Mikro Kecil dan Menengah (SAK EMKM) merupakan Standar Akuntansi Keuangan terbaru dan lebih sederhana dari SAK ETAP, SAK EMKM digunakan UMKM dalam menyusun laporan laba rugi, laporan posisi keuangan dan catatan atas laporan keuangan.

Standar EMKM merupakan SAK baru yang diterbitkan oleh IAI untuk UMKM, dalam rangka mewujudkan UMKM Indonesia yang maju, mandiri, dan modern. Berikut beberapa tujuan SAK EMKM antara lain :

a. Menurut Ikatan Akuntan Indonesia SAK EMKM ditujukan sebagai dasar penyusunan dan pengembangan pedoman atau panduan akuntansi bagi UMKM yang bergerak di berbagai bidang usaha.

b. Menurut (Tri Siwi Agustina, 2019) tujuan SAK EMKM untuk memberikan kemudahan penyusunan laporan keuangan yang bermanfaat bagi sejumlah besar pengguna dalam pengambilan keputusan ekonomik.

c. Menurut (Ernawati, 2016) SAK EMKM bertujuan memudahkan entitas untuk menyusun laporan keuangan serta mendapat akses ke lembaga keuangan sebagai penambahan modal.

d. Dalam Penelitian (Safanah, 2018) SAK EMKM bertujuan memudahkan entitas untuk menyusun laporan keuangan serta mendapat akses ke lembaga keuangan sebagai penambahan modal.

Dari beberapa penjelasan ahli diatas dapat disimpulkan bahwa tujuan SAK EMKM yaitu sebagai dasar untuk menyusun laporan keuangan yang di khususkan untuk Entitas Mikro Kecil dan Menengah UMKM guna mendapatkan penambahan modal dari lembaga keuangan.

Instrumen penerapan SAK EMKM yang digunakan dalam penelitian ini yaitu kesesuaian akun/perkiraan, kesesuaian pengukuran, kesesuaian proses/siklus, dan kesesuaian penyajian.

\section{Ukuran Usaha}

Ukuran secara umum dapat diartikan sebagai suatu perbandingan besar atau kecilnya suatu objek. Ukuran usaha dapat juga sebagai alat untuk mengukur, panjangnya sesuatu, pendapatan pengukuran dan menetukan sesuatu yang dipakai.

Menurut (Ernawati, 2016, hal. 15) mendefinisikan ukuran usaha sebagai berikut: "Ukuran usaha sebagai alat untuk menggambarkan besar kecilnya suatu perusahaan yang dapat dinyatakan dengan total aset atau total penjualan bersih. Semakin besar total aset maupun penjualannya, maka semakin besar pula ukuran suatu perusahaan. Semakin besar aset maka semakin besar modal yang ditanam. Sementara semakin banyak penjualan, maka semakin banyak juga perputaran uang dalam perusahaan" 


\section{Tutik Siswanti, Indah Suryati}

Menurut (Cahyo, 2014) menyatakan bahwa ukuran usaha menggambarkan besar kecilnya suatu perusahaan yang dinyatakan dengan pertumbuhan aktiva yang dimiliki usaha dan peningkatan penjualan bersih yang diperoleh usaha.

Pengukuran yang dilakukan tersebut memiliki manfaat untuk pengelola dapat mengetahui tumbuh dan berkembangnya perusahaan yang dikelola. Menurut (AA.Anwar Prabu Mangkunegoro, 2016, hal. 70) manfaat dari ukuran usaha antara lain:

a. Menelusuri kinerja terhadap harapan pelanggan sehingga akan membawa perusahaan lebih dekat pada pelangganya dan membuat seluruh orang dalam organisasi terlibat dalam upaya memberi kepuasan kepada pelanggan;

b. Memotivasi pemilik untuk mengembangkan kreatifitasnya dengan melihat tumbuh kembangnya usaha.

c. Mengidentifikasi berbagai pemborosan sekaligus mendorong upaya-upaya pengurangan terhadap pemborosan tersebut.

Pada dasarnya pengelompokkan perusahaan dibagi kedalam beberapa kelompok diantaranya perusahaan kecil, sedang, dan besar. Menurut Longenecker dalam (Suastini, 2019) cara yang dapat digunakan untuk mengukur sebuah perusahaan, yaitu dilihat dari jumlah karyawan, volume penjualan, dan nilai aset dari perusahaan tersebut. Menurut (UU No.20 Tahun 2008, 2008) dibagi kedalam empat kategori yaitu usaha mikto, usaha kecil, usaha menengah, dan usaha besar.

Penentuan pengukuran usaha dapat ditentukan dari faktor utama yang mempengaruhi. Dalam penelitian (Hartono dan Hartomo.D, 2016) Ukuran perusahaan memiliki tiga faktor utama yaitu:

a. Besarnya total aktiva, total aktiva merupakan total aset yang dimiliki perusahaan dalam melaksanakan kegiatan usahanya seperti: peralatan yang dimiliki, persediaan yang dimiliki, dan lain-lain

b. Besarnya hasil penjualan, penjualan dalam hal ini merupakan pendapatan uang masuk yang diterima selama kegiatan usaha.

c. Besarnya kapitalisasi pasar, Besar atau kecilnya harga perusahaan di Bursa Efek Indonesia.

Instrumen Ukuran Perusahaan yang digunakan dalam penelitian ini yaitu kepemilikan aset, modal usaha, penjualan, dan laba usaha,

\section{Kompetensi Sumber Daya Manusia}

Menurut (Wibowo, 2017, hal. 271), "Kompetensi sumber daya manusia adalah suatu kemampuan untuk melaksanakan atau melakukan suatu pekerjaan yang dilandasi atas keterampilan dan pengetahuan serta didukung oleh sikap kerja yang didukung oleh sikap kerja yang dituntut oleh pekerjaan tersebut

Menurut Wirawan dalam penelitian (J. Oliver, 2014, hal. 15), "Kompetensi sumber daya manusia adalah melukiskan karakteristik pengetahuan, keterampilan, perilaku, dan pengalaman yang dimiliki manusia untuk melakukan suatu pekerjaan atau peran tertentu secara efektif.“

Kompetensi merupakan kemampuan kerja setiap indiviudu dalam organisasi yang mencakup aspek pengetahuan dan keterampilan sesuai dengan standard yang telah ditetapkan yang mengacu pada lingkungan kerja. Kompetensi sangat dibutuhkan dalam setiap proses 


\section{Tutik Siswanti, Indah Suryati}

sumber daya manusia. Hal tersebut bertujuan agar semua pegawai dapat melaksanakan tugasnya secara profesional, efektif, dan efisien. Pegawai yang tidak mempunyai pengetahuan yang cukup akan mengalamai kesulitan dalam beberapa hal dan akan mengakibatkan pemborosan bahan, waktu, dan tenaga.

Menurut Ruky dalam jurnal penelitian (Ningsih, 2017, pp. 6-7) terdapat beberapa manfaat dari kompetensi sumber daya manusia, antara lain adalah memperjelas standar kerja dan arahan yang ingin dicapai. Karyawan yang memiliki komptensi akan lebih mudah dalam menyelesaikan pekerjaan sesuai dengan standar dan pedoman kerja yang telah ditentukan.

Salah satu tipe kompetisi (Wibowo, 2017, hal. 275-276), adalah Self Management Competency (Kompetensi Manajemen Mandiri), kompetensi yang mempunyai keterampilan dalam pengambilan keputusan bisnis, bekerja dalam sistem, dan membangkitkan pendapatan. Kompetensi ini antara lain berkaitan dengan softskill pada bidang tertentu yang dimiliki karyawan. Dengan memiliki ketrampilan dan keahlian sesuai dengan yang dibutuhkan, maka karyawan tersebut akan dapat menghasilkan pekerjaan yang maksimal sesuai dengan ketentuan-ketentuan yang telah ditargetkan perusahaan.

Menurut Zwell dalam (Wibowo, 2017, hal. 283-285) mengungkapkan bahwa terdapat beberapa faktor yang dapat mempengaruhi kompetensi sumber daya manusia, antara lain :

a. Keterampilan ; Ketrampilan sangat dibutuhkan pada kebanyakan kompetensi. Pengembagan keterampilan yang secara spesifik berkaitan dengan kompetensi dapat berdampak baik pada budaya organisasi dan kompetensi individual.

b. Pengalaman; Pengalaman merupakan aspek lain kompetensi yang dapat berubah dengan perjalanan waktu dan perubahan lingkungan.

Instrumen Kompetensi SDM dalam penelitian ini adalah latar belakang pendidikan, pengalaman, ketrampilan, pemahaman, dan pengetahuan pada bidang akuntansi

\section{Metode Penelitian}

Metode penelitian yang digunakan dalam penelitian ini metode kuantitatif. Metode penelitian kuantitatif adalah metode penelitian yang didasarkan pada filsafat positivisme, digunakan dalam meneliti sampel dan populasi penelitian, teknik pengambilan sampel umumnya dilakukan secara acak atau random sampling, sedangkan pengumpulan datanya dilakukan dengan cara memanfaatkan instrumen penelitian yang dipakai, analisis data yang digunakan bersifat kuantitatif dan bisa diukur dengan tujuan untuk menguji hipotesa yang sudah ditetapkan sebelumnya." (Sugiyono, 2017)

Metode penelitian yang digunakan adalah deskriptif asosiatif. Menurut (Sugiyono, 2017, hal. 159) hubungan kausalitas adalah hubungan yang bersifat sebab akibat. Jadi variabel independen (mempengaruhi) dan variabel dependen (dipengaruhi). Dalam hal ini variabel ukuran usaha dan kompetensi sumber daya manusia sebagai yang mempengaruhi atau penyebab dan variabel penerapan SAK-EMKM dalam penyusunan laporan keuangan sebagai yang dipengaruhi atau akibat.

Metode pengumpulan data yang digunakan pada penelitian ini adalah menggunakan metode penyebaran kuiseoner (angket). Menurut (Sugiyono, 2017), kuisioner adalah teknik pengumpulan data yang dilakukan dengan cara memberi beberapa pertanyaan dan pernyataan tertulis kepada responden, kemudian akan dijawab oleh responden. Kuisioner dalam penelitian ini bersifat tertutup, dimana jawaban sudah disediakan dan responden hanya memilih jawaban tersebut. Pengumpulan data dilakukan dalam jangka waktu 2 bulan, yaitu bulan Januari s.d Februari 2020. 
Populasi dalam penelitian ini merupakan pelaku usaha UMKM di wilayah Kecamatan Maksar, Jakarta Timur. Populasi dalam penelitian ini tidak diketahui jumlahnya sehingga untuk menghitung jumlah sampel minimum yang dibutuhkan menggunakan formula Lemeshow untuk populasi yang tidak diketahui (Sugiyono, 2017) ;

$$
n=\frac{Z^{2} x P(1-P)}{d^{2}}
$$

Keterangan:

$\mathrm{n}=$ Jumlah sampel

$\mathrm{z}=$ skor $\mathrm{z}$ pada kepercayaan $95 \%=1,96$

$\mathrm{p}=$ maksimal estimasi $=0,5$

$\mathrm{d}=$ alpha (0.10) atau sampling error $=10 \%$

Jika berdasarkan rumus tersebut maka n yang didapatkan adalah 96,04, sehingga pada penelitian ini sample penelitian sejumlah 97 pelaku UMKM di Kecamatan Makasar, Jakarta Timur.

Teknik pengambilan sampel dalam penelitian ini menggunakan metode non probability sampling. Non probability sampling merupakan teknik pengambilan sampel yang tidak memberikan peluang atau kesempatan yang sama bagi setiap unsur atau anggota populasi untuk dipilih menjadi anggota sampel (Imam Ghozali, 2013). Cara yang digunakan adalah convenience sampling yaitu sebuah teknik penentuan sampel berdasarkan kebetulan saja, peneliti memilih populasi berdasarkan yang dirasa bersedia untuk menjadi responden dan dapat memberikan informasi yang dibutuhkan.

\section{Hasil Pembahasan}

\section{Uji Instrumen Penelitian}

Uji instrumen penelitian adalah pengujian yang dilakukan untuk mengukur tingkat validitas dan realibilitas dari instrumen penelitian. Dalam penelitian ini akan melakukan uji validitas terhadap 20 responden. Dengan nilai $r$ tabel pada tingkat signifikan 0,05 dua arah (two-tails), atau pada tingkat signifikan $0,05: 2=0,025$ dengan $\mathrm{n}$ sebanyak 20 , sehingga $\mathrm{df}=$ $\mathrm{N}-2(20-2=18)$, maka df atau $\mathrm{r}_{\text {tabel }}$ menunjukkan nilai 0,4438.Jika rhitung $>$ rtabel, maka disimpulkan bahwa instrumen yang digunakan dalam penelitian ini valid. Selain itu juga dilakukan uji reliabilitas dengan menggunakan Cronbach Alphadengan, jika nilai Cronbach Alpha $>$ 0,6 maka, dikatakan instrumen yang digunakan dalam penelitian ini reliabel. (Imam Ghozali, 2013) 
Tutik Siswanti, Indah Suryati

Tabel 1. Rekapitulasi Hasil Uji Validitas dan Uji Reliabilitas

\begin{tabular}{|c|c|c|c|c|c|c|}
\hline \multirow[t]{2}{*}{ Pertanyaan } & \multicolumn{2}{|c|}{ Ukuran Perusahaan $\left(\mathrm{X}_{1}\right)$} & \multicolumn{2}{|c|}{ Kompetensi SDM $\left(\mathrm{X}_{2}\right)$} & \multicolumn{2}{|c|}{$\begin{array}{c}\text { Penerapan SAK EMKM } \\
\text { (Y) }\end{array}$} \\
\hline & $\mathrm{r}_{\text {hitung }}$ & $\begin{array}{l}\text { Cronbach } \\
\text { Alpha }\end{array}$ & $\mathrm{r}_{\text {hitung }}$ & $\begin{array}{l}\text { Cronbach } \\
\text { Alpha }\end{array}$ & $r_{\text {hitung }}$ & $\begin{array}{l}\text { Cronbach } \\
\text { Alpha }\end{array}$ \\
\hline 1 & 0,773 & \multirow{10}{*}{0,759} & 0,607 & \multirow{10}{*}{0,762} & 0,485 & \multirow{10}{*}{0,701} \\
\hline 2 & 0,598 & & 0,686 & & 0,486 & \\
\hline 3 & 0,773 & & 0,461 & & 0,517 & \\
\hline 4 & 0,632 & & 0,592 & & 0,458 & \\
\hline 5 & 0,618 & & 0,796 & & 0,615 & \\
\hline 6 & 0,470 & & 0,817 & & 0,601 & \\
\hline 7 & 0,653 & & 0,748 & & 0,528 & \\
\hline 8 & 0,731 & & 0,694 & & 0,492 & \\
\hline 9 & 0,619 & & 0,785 & & 0,604 & \\
\hline 10 & 0,704 & & 0,691 & & 0,563 & \\
\hline
\end{tabular}

Berdasarkan tabel diatas menunjukkan hasil reliabilitas ( $\mathrm{rhitung}>\mathrm{rtabel}$,) dan nilai Cronbach Alpha $>0,6$, dengan demikian dapat disimpulkan bahwa seluruh instrumen yang digunakan dalam penelitian ini valid dan reliabel.

\section{Uji Normalitas}

Uji normalitas ini menggunakan metode Kolmogrov-Smirnov. Dasar pengambilan pada Uji Normalitas adalah jika nilai signifikan yang diperoleh > 0,05 maka data sampel dari populasi tersebut berdistribusi normal, sebaliknya jika nilai signifikan yang yang diperoleh < 0,05, maka data sampel dari populasi tersebut tidak berdistribusi normal. (Imam Ghozali, 2013)

Tabel 2. Hasil Uji Normalitas

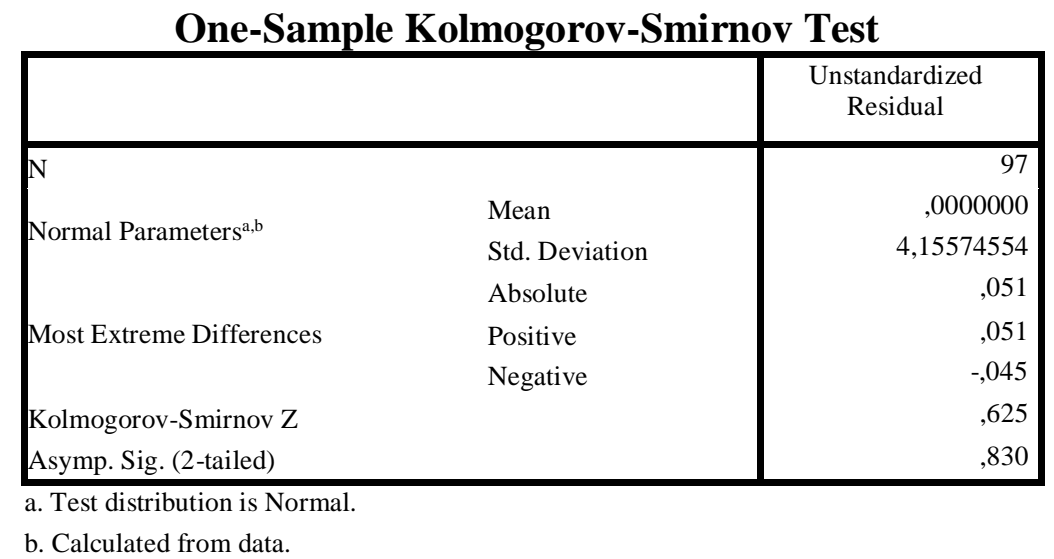

Sumber : Data Primer Diolah oleh Peneliti (2019)

Dari tabel diatas menunjukkan Asymp Sig (2-tailed) sebesar 0,83> dari 0,05 yang berarti residual (data) yang dibentuk berdistribusi normal.

\section{Regresi Linear Berganda}

Analisis regresi linear berganda untuk mengetahui dan meramalkan bagaimana keadaan (naik turunnya) variabel dependen (kriterium), bila dua atau lebih variabel independen sebagai 
faktor prediator dimanipulasi (dinaikan atau diturunkan nilainya). (Sugiyono, 2017).Adapun hasil pengolahan output persamaan regresi linier berganda sebagai berikut:

\section{Tabel 3. Hasil Regresi Linear Berganda}

\section{Coefficients $^{\mathrm{a}}$}

\begin{tabular}{|c|c|c|c|c|c|c|}
\hline \multirow[t]{2}{*}{ Mod } & & \multicolumn{2}{|c|}{ Unstandardized Coefficients } & \multirow{2}{*}{$\begin{array}{c}\begin{array}{c}\text { Standardized } \\
\text { Coefficients }\end{array} \\
\text { Beta }\end{array}$} & \multirow[t]{2}{*}{$\mathrm{t}$} & \multirow[t]{2}{*}{ Sig. } \\
\hline & & $\mathrm{B}$ & Std. Error & & & \\
\hline \multirow{3}{*}{1} & (Constant) & 2,449 & 2,834 & & 7,215 &, 002 \\
\hline & UkuranUsaha(X1) & ,241 & ,075 &, 234 & 3,413 &, 000 \\
\hline & Kompetensi SDM (X2) & , 152 & 064 &, 167 & 8,301 &, 016 \\
\hline
\end{tabular}

a. Dependent Variable: Penerapan SAK EMKM(Y)

Berdasarkan tabel tersebut, maka hasil persamaan regresi adalah :

$\mathrm{Y}=2,449+0,241 \mathrm{X}_{1}+0,152 \mathrm{X}_{2}$

Interpretasi dari persamaan regresi adalah :

a. Nilai konstanta (a) bernilai positif sebesar 2,449 artinya apabila variabel ukuran usaha dan kompetensi SDM konstan atau sama dengan 0, maka penerapan SAK EMKM nilainya sebesar 2,449.

b. Nilai koefisien variabel ukuran usaha bernilai positif sebesar 0,241. Hal ini berarti variabel ukuran usaha memiliki hubungan positif dan searah dengan Penerapan SAK EMKM. Hubungan ditunjukkan, apabila ukuran usaha naik atau turun sebesar satu satuan, maka akan mengakibatkan kenaikan dan penurunan penerapan SAK EMKM sebesar 0,241, dengan asumsi variabel lain konstan.

c. Nilia koefisien variabel kompetensi SDM positif sebesar 0,152. Hal ini berarti variabel kompetensi SDM memiliki hubungan positif dan searah dengan penerapan SAK EMKM. Jika kompetensi SDM naik atau turun satu satuan, maka akan mengakibatkan kenaikan atau penurunan penerapan SAK EMKM sebesar 0,152, dengan asumsi variabel lain konstan.

\section{Uji Asumsi Klasik}

\section{Uji Multikolinearitas}

Alat uji yang digunakan adalah Variance Inflation Factor (VIF) dan Tolerance. Jika nilai VIF < 10,00 tidak terjadi multikolinearitas, dan jika nilai VIF >10,00 terjadi multikolinearitas, dan jika Tolerance $>0,10$ tidak terjadi multikolinearitas, dan jika nilai Tolerance< 0,10 artinya terjadi multikolinearitas. (Imam Ghozali, 2013). Hasil uji multikolinearitas adalah sebagai berikut : 
Tabel 4. Hasil Uji Multikolinearitas Coefficients $^{\mathrm{a}}$

\begin{tabular}{|c|c|c|c|c|c|c|c|}
\hline \multirow[t]{2}{*}{ Model } & \multicolumn{2}{|c|}{$\begin{array}{c}\text { Unstandardized } \\
\text { Coefficients }\end{array}$} & \multirow{2}{*}{$\begin{array}{c}\text { Standardized } \\
\text { Coefficients } \\
\text { Beta }\end{array}$} & \multirow[t]{2}{*}{$\mathrm{t}$} & \multirow[t]{2}{*}{ Sig. } & \multicolumn{2}{|c|}{ Collinearity Statistics } \\
\hline & $\mathrm{B}$ & Std. Error & & & & Tolerance & VIF \\
\hline (Constant) & 2,449 & 2,834 & & 7,215 &, 002 & & \\
\hline Ukuran Usaha(X1) & ,241 &, 075 & ,234 & 3,413 &, 000 & ,998 & 1,002 \\
\hline Kompetensi SDM (X2) & , 152 & ,064 & , 167 & 8,301 &, 016 & ,998 & 1,002 \\
\hline
\end{tabular}

a. Dependent Variable: Penerapan SAK EMKM(Y)

Sumber : Data Primer Diolah oleh Peneliti (2019)

Berdasarkan tabel diatas menunjukkan Nilai Tolerance variabel Ukuran Usaha $\left(\mathrm{X}_{1}\right)$ dan variabel Kompetensi SDM $\left(\mathrm{X}_{2}\right)$ sebesar 0,998 > 0,10. Sementara itu, nilai VIF variabel Ukuran Usaha $\left(X_{1}\right)$ dan variabel Kompetensi SDM $\left(X_{2}\right)$ yakni sebesar 1,002 < 10,00. Dengan demikian, maka kedua variabel bebas dalam penelitian ini tidak terjadi multikolinearitas

\section{Uji Heteroskedastisitas}

Pengujian pada penelitian ini dengan menggunakan grafik plot antara nilai prediksi variabel dependen yaitu ZPRED dengan residualnya SRESID. Apabila tidak ada pola yang jelas, serta titik-titik menyebar di atas dan di bawah angka 0 pada sumbu Y, maka dapat disimpulkan tidak terdapat heterokedastisitas. (Imam Ghozali, 2013).Hasil Uji heterokedastisitas sebagai berikut :

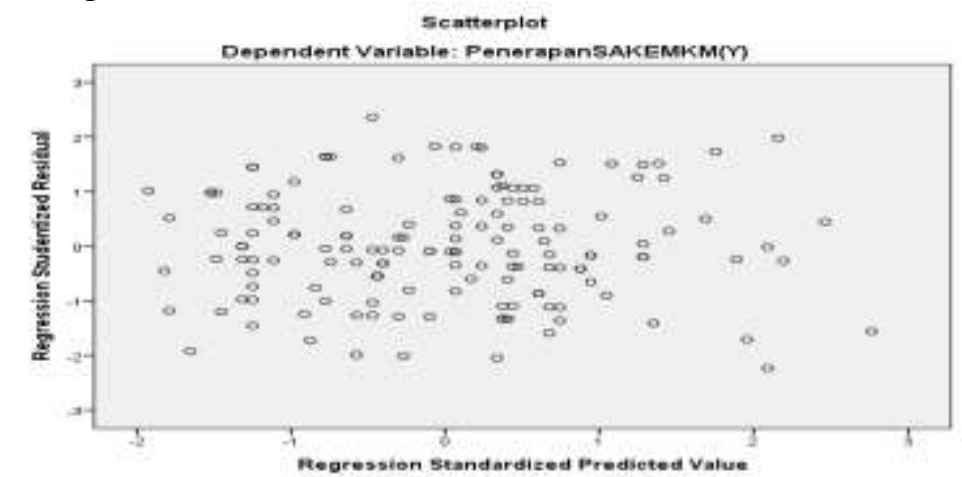

Gambar 1. Grafik Scatterplot Uji Heteroskedastisitas

Sumber : Data Primer Diolah oleh Peneliti (2019)

Berdasarkan gambar diatas menunjukkan pola yang dihasilkan tidak berbentuk pola yang jelas titik-titik data menyebar diatas dan dibawah atau disekitar angka 0 , sehingga dapat disimpulkan tidak terjadi heteroskedastisitas.

\section{Uji Hipotesis}

\section{Uji Hipotesis Parsial}

Uji t (t-test) untuk mengukur pengaruh antara varaibel bebas varaibel terikat secara parsial. Pengujian ini dilakukan untuk mengetahui signifikan peran secara parsial antara variabel independen (Ukuran Usaha dan Kompetensi SDM) terhadap variabel dependen (Penerapan SAK EMKM).Pengujian dilakukan dengan membandingkan antara $t_{\text {hitung }}$ dengan 
$\mathrm{t}_{\text {tabel. }}$. Jika nilai $\mathrm{t}_{\text {hitung }}<\mathrm{t}_{\text {tabel }}$, hal ini berarti varaibel bebas mempengaruhi variabel terikat, dan sebaliknya. Nilai $\mathrm{t}_{\text {tabel }}=\mathrm{t}(\mathrm{a} / 2 ; \mathrm{n}-\mathrm{k}-1)=\mathrm{t}(0,025 ; 148)=1,976$. Tingkat signifikansi pengaruh antara variabel bebas dengan variabel terikat dapat diukur dengan membandingkan antara nilai signifikansi dengan tingkat signifikansi (5\%0. Jika nilai signifikansinya $<0,05$, maka dapat disimpulkan jika pengaruh antara varaibel bebas dengan variabel terikat signifikan, dan sebaliknya. Hasil uji t pada hipotesis parsial dapat dilihat pada tabel 3 atau tabel 4.

1) Hasil Uji Hipotesis pengaruh antara Ukuran Usaha dengan Penerapan SAK EMKM. Nilai thitung sebesar 3,413 $>t_{\text {tabel }}$ sebesar 1,976 dan nilai signifikansi sebesar $0,000<0,05$, maka dapat disimpulkan, variabel ukuran usaha berpengaruh signifikan terhadap penerapan SAK EMKM.

2) Hasil Uji Hipotesis Pengaruh antara Variabel Komptensi SDM dengan Penerapan SAK EMKM . Nilai $t_{\text {hitung }}$ sebesar 8,301 $>\mathrm{t}_{\text {tabel }}$ sebesar 1,976 dan nilai signifikansi sebesar $0,016<0,05$, maka dapat disimpulkan, kompetensi SDM berpengaruh signifikan terhadap penerapan SAK EMKM.

\section{Uji Hipotesis Simultan}

Pengujian ini dilakukan untuk mengetahui pengaruh secara bersama-sama (simultan) variabel Independen (Ukuran Usaha dan Kompetensi SDM) terhadap variabel Dependen (Penerapan SAK EMKM). Jika nilai Fhitung> Ftabel, maka dapat disimpulkan jika secara bersama-sama variabel bebas berpengaruh terhadap variabel terikat, dan sebailnya. Nila $F_{\text {tabel }}$ $(\mathrm{k} ; \mathrm{n}-\mathrm{k})=(3 ; 148)=3,06$. Out hasil pengolahan uji hipotesis simultan adalah sebagai berikut:

Tabel 5. Hasil Uji F Hipotesis Simultan ANOVA $^{\mathrm{a}}$

\begin{tabular}{|rl|r|r|r|r|r|}
\hline Model & & Sum of Squares & \multicolumn{1}{|c|}{ Df } & Mean Square & \multicolumn{1}{c|}{ F } & Sig. \\
\hline \multirow{4}{*}{1} & Regression & 14,182 & 2 & 7,091 & 7,405 &, $000^{\mathrm{b}}$ \\
& Residual & 2590,533 & 148 & 17,504 & & \\
& Total & 2604,715 & 150 & & & \\
\hline
\end{tabular}

a. Dependent Variable: PenerapanSAKEMKM(Y)

b. Predictors: (Constant), Kompetensi SDM(X2), UkuranUsaha(X1)

Sumber : Data Primer Diolah oleh Peneliti (2019)

Dari hasil pengolahan data di atas menunjukkan nilai $\mathrm{F}_{\text {hitung }}=7,405>\mathrm{F}_{\text {tabel }}=3,06$, dan nilai signifikansi $0,000<0,05$, yang berarti bahwa Ukuran Usaha dan Kompetensi SDM secara bersama-sama (simultan) berpengaruh signifikan terhadap Penerapan SAK EMKM.

\section{Koefisien Determinasi}

Koefisien Dseterminasi digunakan untuk mengetahui seberapa besar kontribusi varian variabel bebas (Ukuran Usaha dan Kompetensi SDM) mampu menjelaskan varian atau perubahan variabel terikat (Penerapan SAK EMKM). Hasiil ouput koefisien determinasi disajikan pada tabel berikut ini. 
Tutik Siswanti, Indah Suryati

\section{Tabel 6. Nilai Koefisien Determinasi}

\begin{tabular}{|l|r|r|r|r|}
\hline Model & R & R Square & Adjusted R Square & $\begin{array}{c}\text { Std. Error of the } \\
\text { Estimate }\end{array}$ \\
\hline 1 &, $874^{\mathrm{a}}$ &, 675 &, 418 & 5,487 \\
\hline
\end{tabular}
a. Predictors: (Constant), Kompetensi SDM(X2), Ukuran Usaha(X1)
Sumber : Data Primer Diolah oleh Peneliti (2019)

Berdasarkan hasil pengolahan data di atas, maka dapat diketahui nilai R Square sebesar 0,375 hal ini menunjukkan bahwa varian variabel bebas yaitu Ukuran usaha (X1) dan Kompetensi SDM (X2) mampu menjelaskan varian dari variabel terikat yaitu Penerapan SAK EMKM (Y) sebesar 67,5\% sedangkan sebesar 32,5\% dijelaskan oleh variabel lain yang tidak digunakan dalam pengukuran penelitian ini.

\section{Pebahasan Hasil Analisis Data}

Pengaruh ukuran usaha UMKM terhadap Penerapan SAK EMKM, dengan koefisien regresi sebesar 0,241, dan hasil uji hipotesis parsial yang menunujukkan nilai $t_{\text {hitung }}$ sebesar $3,413>\mathrm{t}_{\text {tabel }}$ sebesar 1,976 dan nilai signifikansi sebesar $0,000<0,05$, hal ini berarti menunjukkan ukuran usaha memiliki pengaruh serta arah positif dan signifikan terhadap penerapan SAK EMKM. Kondisi demikian menunjukkan bahwa ukuran usaha UMKM memiliki keterkaitan dengan penerapan SAK EMKM dalam penyusunan laporan keungan. UMKM yang sudah tumbuh dan berkembang dari segi harta maupun penghasilan akan membutuhkan infromasi keuangan berupa laporan keuangan yang lebih baik dan lebih tertata lagi agar mengetahui pertumbuhan asetnya, pertumbuhan labanya dari waktu-waktu karena setiap usaha memiliki target untuk lebih berkembang lagi. Usaha yang sudah berkembang juga membutuhkan manajemen penyusunan laporan keuangan untuk menyusun laporan keuangan, sehingga membutuhkan suatu standar yang dapat digunakan dalam menyusun laporan keuangan untuk mengembangkan usahanya lagi, agar dapat juga digunakan sebagai bahan evaluasi, mengukur dan dapat melihat pertumbuhan usahanya dari waktu ke waktu, dalam hal ini standar yang digunakan untuk usaha UMKM adalah SAK EMKM. Dengan demikian ukuran usaha menjadi salah satu sasaran dan tujuan sosialisasi SAK EMKM. Semakin besarnya ukuran usaha UMKM akan menjadikan penerapan SAK EMKM semakin dibutuhkan

Hasil penelitian menunjukkan koefisien regresi positif 0,152 , dan nilai thitung sebesar $8,301>\mathrm{t}_{\text {tabel }}$ sebesar 1,976, serta nilai signifikansi sebesar 0,016 $<0,05$, artinya bahwa kompetensi SDM berpengaruh positif dan searah, serta signifikan terhadap UMKM dalam menerapkan SAK EMKM dalam menyusun laporan keuangan. Kemampuan SDM dalam memahami, mengetahui, cara penyusunan laporan keuangan dengan standar yang benar sangat bepengaruh bagi UMKM dalam menerapkan SAK EMKM. Oleh karena itu UMKM harus mulai memikirkan untuk meningkatkan kompetensi SDM, atau melakukan rekruitmen SDM yang memiliki kompetensi bidang akuntansi, jika ingin menerapkan SAK EMKM dalam penyusunan laporan keuangannya.

\section{Kesimpulan}

Keimpulan dari hasil pengolahan data dan pembahasan dalam penelitian ini tentang pengaruh ukuran usaha dan Kompetensi SDM terhadap penerapan SAK EMKM pada usaha jasa pelayanan laundry di Kecamatan Makasar, dapat menghasilkan beberapa kesimpulan. 


\section{Tutik Siswanti, Indah Suryati}

Berdasarkan hasil uji hipotesis parsial pertama $\left(\mathrm{H}_{1}\right)$, menunjukkan bahwa nilai thitung $>$ $t_{\text {tabel}}$, dan nilai siginifikansi $<0,05$, sehingga Hipotesisis nul (Ho) ditolak dan Hipotesis alternatif (Ha) diterima, hal ini dapat disimpulkan bahwa dalam penelitian ini variabel ukuran usaha secara parsial memiliki hubungan positif dan searah, serta berpengaruh signifikan terhadap Penerapan SAK SAK EMKM.

Hasil uji hipotesis parsial kedua $\left(\mathrm{H}_{2}\right)$ menunjukkan, bahwa nilai $t_{\text {hitung }}>\mathrm{t}_{\text {tabel }}$, dan nilai siginifikansi $<0,05$, sehingga Hipotesisis nul (Ho) ditolak dan Hipotesis alternatif (Ha) diterima, hal ini dapat disimpulkan bahwa dalam penelitian ini variabel kompetensi SDM secara parsial memiliki hubungan positif dan searah serta berpengaruh signifikan terhadap Penerapan SAK EMKM.

Dalam uji hipotesis ke 3 (H3), dimana menguji secara simultan pengaruh variabel bebas secara bersama-sama terhadap variabel terikat, menunjukkan nila Fhitung > Ftabel, serta nilai signifikansi < 0,05, dengan demikian Hipotesisis nul (Ho) ditolak dan Hipotesis alternatif (Ha) diterima, sehingga dapat disimpulkan bahwa variabel ukuran usaha dan kompetensi SDM secara simultan berpengaruh signifikan terhadap penerapan SAK EMKM. Hasil ini diperkuat dengan nilai koefisien determinasi, dimana varian dari variabel bebas mampu menjelaskan varian variabel terikat sebesar $67,5 \%$.

\section{Daftar Pustaka}

AA.Anwar Prabu Mangkunegoro. (2016). Kinerja Perusahaan. Bnadung: Remaja Rosdakarya. Cahyo, N. (2014). Analisis Pengaruh Pertumbuhan Penjualan, Ukuran perusahaan dan Umur Perusahaan terhadap Struktur Modal Usaha Kecil dan Menengah Kerajinan Kuningan di Kabupaten Pati. Jurnal Manajemen Universitas Semarang.

David, W. (2018). Akuntansi UMKM. Yogjakarta: Grava Media.

Ernawati. (2016). Penerapan Akuntansi dasar pada Usaha Kecil Menengah di Kota Banjarmasin. Jurnal Penelitian Ilmu Ekonomi Wiga. STIE Indonesia Banjarmasin, 35.

Hartono dan Hartomo.D. (2016). Faktor-faktor yang mempengaruhi Perkembangan UMKM di Surakarta. Surakarta: Jurnal Bisnis dan Manajemen, 14 (1), 15.

IAI. (2019). Strandar Akuntansi Keuangan Entitas Mikro Kecil dan Menengah. Jakarta: Dewan Standar Akuntansi Keuangan IAI.

Imam Ghozali. (2013). Aplikasi Analisis Multivariate dengan Program IBM SPSS 21 Updatae PLS Regresi. Semarang: Badan Penerbit Universitas Diponegoro.

J. Oliver. (2014). Pengaruh Kompetensi Sumber Daya Manusia Dan Penerapan Sistem Akuntansi Keuangan Daerah Terhadap Kualitas Laporan Keuangan Daerah Kegiatan. Journal of Chemical Information and Modeling, 53(9), https://doi.org/10.1017/CBO978110, 15.

Muslichah, N. E. (2018). Akuntansi UMKM. Sidoarjo: Indonesia Pustaka.

Purba, M. (2019). Analisis Penerapan SAK EMKM. Program D Akuntansi \& Batam U.P, 5563.

Safanah. (2018). Sumber Modal Pada Usaha kecil Makanan Ringan Desa Kengonan Gresik. Jurnal Riset Enterpreneurship, 64-76.

Suastini, D. Y. (2019). Pengaruh Kualitas Sumber daya Manusia dan Ukuran perusahaan Terhadap Pemahaman UMKM dalam menusun Laporan Keuangan Berdasarkan SAK EMKM (Studi Kasus di Kecamatan Buleleng). E-Jurnal S1 Ak Universitas Pendidikan Ganesha, 166 - 178.

Sugiyono. (2017). Metode Penelitian Kuantitatif, Kualitatif, dan R\&D. Bandung: CV.Alfabeta. 
Tri Siwi Agustina. (2019). Kewirausahaan di Era Revolusi Industri 4.0. Bogor: Mitra Wacana Media.

Uno M.O, K. d. (2019, Juli). Analysis of the Implementation of financial accounting standard of Micro, Small, and Medium entities (SAK EMKM) in Micro, Small, and Medium enterprise (Case Study in Rumah Karawo in Gorontalo City). Jurnal EMBA, Vol 7, No. 3, ISSN 3887-3898, 38.

Wibowo. (2017). Manajemen Kinerja.pdf (Edisi kelima). Jakarta: Rajawali Pers.

Yuli Rawun, d. O. (2019). Penerapan Standar Akuntansi Keuangan EMKM Dalam Penyusunan laporan Keuangan pada UMKM (Studi Kasus UMKM Pesisir di Kecamatan Malalayang, Manado). Jurnal Akuntansi Keuangan dan Bisnis, Sekolah Tinggi Ilmu Ekonomi Eben Haezer, Manado, 57. 